\title{
Abnormal levels of aqueous humor trace elements in patients with cytomegalovirus retinitis
}

\author{
Yalin Zhou ${ }^{1}$ Fei Hong ${ }^{2} \cdot$ Xiaojuan $\mathrm{Wang}^{2} \cdot$ Jing Feng ${ }^{3} \cdot$ Dan $\mathrm{Zhu}^{2} \cdot$ Yajun $\mathrm{Xu}^{1} \cdot$ Yong Tao $^{3}$
}

Received: 8 September 2018 / Revised: 11 March 2019 / Accepted: 7 April 2019 / Published online: 7 May 2019

(c) The Royal College of Ophthalmologists 2019

\begin{abstract}
Purpose To investigate the alterations of trace elements levels in aqueous humor of patients with cytomegalovirus retinitis (CMVR).

Methods A total of 15 eyes of 11 patients with CMVR and 24 eyes of 24 patients with senile cataract as control group were enrolled. Aqueous humor samples were assessed for calcium $(\mathrm{Ca})$, potassium $(\mathrm{K})$, magnesium $(\mathrm{Mg})$, sodium $(\mathrm{Na})$, phosphorus $(\mathrm{P})$, titanium $(\mathrm{Ti})$, vanadium $(\mathrm{V})$, chromium $(\mathrm{Cr})$, manganese $(\mathrm{Mn})$, iron $(\mathrm{Fe})$, nickel $(\mathrm{Ni})$, copper $(\mathrm{Cu})$, zinc $(\mathrm{Zn})$, selenium ( $\mathrm{Se})$, strontium $(\mathrm{Sr})$, and lead $(\mathrm{Pb})$ by using inductively coupled-plasma-mass-spectrometry. Meanwhile, we examined the concentration of the CMV DNA load by using PCR and the concentration of interleukin (IL)- 8 by using a cytometric bead array.

Results In patients with CMVR, the aqueous humor levels of $\mathrm{P}$ and $\mathrm{Cu}$ were significantly higher than those of controls $(p<0.001, p<0.001$, respectively). However, levels of $\mathrm{K}$ and $\mathrm{Mg}$ were significantly lower in patients with CMVR $(p<0.001, p<0.001$, respectively). The Spearman correlation test showed that the concentration of IL-8 in the aqueous humor was significantly associated with the aqueous level of $\mathrm{Cu}(p=0.009, r=0.646)$ and $\mathrm{Se}(p=0.031, r=0.558)$. In addition, the concentration of CMV DNA load in the aqueous humor was significantly associated with the aqueous level of $\mathrm{Ca}(p=0.027, r=-0.568)$, $\mathrm{Mn}(p=0.020, r=0.593)$, and $\mathrm{Cu}(p=0.043, r=0.527)$.

Conclusions Our preliminary results demonstrated that the abnormal aqueous levels of trace elements $(\mathrm{P}$ and $\mathrm{Cu})$ in $\mathrm{CMVR}$ patients. Thus, the roles of trace element changes in the development of CMVR and the influence of intraocular trace element for the prognosis of CMVR warrant further investigations.
\end{abstract}

These authors contributed equally: Y. Zhou, F. Hong, X. Wang, J. Feng

Yajun Xu

xuyajun@bjmu.edu.cn

$\triangle$ Yong Tao taoyong@bjcyh.com

1 Department of Nutrition and Food Hygiene, School of Public Health, Peking University, Beijing, China

2 Department of Ophthalmology, Affiliated Hospital of Inner Mongolia Medical University, Hohhot, Inner Mongolia, China

3 Department of Ophthalmology, Beijing Chaoyang Hospital, Capital Medical University, Beijing, China

\section{Introduction}

Cytomegalovirus retinitis (CMVR) is a common opportunistic infection that afflicts immunocompromised patients, whose previously effective CMV-specific T-cell response has decreased owing to disease (AIDS) or immunosuppressive treatment (including chemotherapy for malignant disease) $[1,2]$. Immune recovery has resulted in an approximate $80 \%$ reduction in the incidence of CMVR, and patients with CMVR who have immune recovery are less likely to have progression of retinitis [3-5].

Trace elements are chemical elements needed in minute amounts for micronutrient homeostasis, which plays a major role in maintaining a healthy immune system [6]. Both a deficiency and an excess of trace elements can cause harm, so the homeostasis of the elements is strictly regulated [7]. There is some evidence that copper and zinc play a key factor in retinal function and are essential for antioxidant defense mechanisms, which are important for 
the survival of the retina, which is routinely exposed to high levels of oxidative stress from light and metabolic processes [8]. Therefore, a few studies focus on the role of trace elements in age-related macular degeneration (AMD) and retinitis pigmentosa $[9,10]$. In addition to increased oxidative damage in the presence of iron and copper, alterations in the functions of some enzymes involved in oxidative stress and in metabolisms of some elements present in the structure of these enzymes have been reported in Behcet's disease [11]. That is to say, trace element homeostasis may also be disturbed by the inflammation and infection [12]. However, there is a lack of information about possible influence of trace element homeostasis in CMVR. We try to figure out the changes in the aqueous level of trace elements in patients with CMVR.

\section{Materials and methods}

\section{Patients}

Fifteen eyes of 11 patients with CMVR who underwent multiple intravitreal injections of ganciclovir and 24 eyes of 24 patients with senile cataract who underwent cataract removal and implant of intraocular lens in our department were enrolled in this study. The diagnosis of active CMR was confirmed by immunosuppression history, typical ocular changes and positive CMV DNA in the aqueous humor by polymerase chain reaction (PCR).

\section{Treatment of cytomegalovirus retinitis}

All of the patients received intravitreal injection of ganciclovir (IVG), which was started immediately when they were diagnosed as CMVR. The injection method was briefly described in detail as previous reports [13, 14]. Totally, $3.0 \mathrm{mg}$ ganciclovir was injected with a 27 -gauge needle transconjunctivally at $3-3.5 \mathrm{~mm}$ from the limbus. Then, an antibiotic ointment (polymyxin and neomycine) was applied.

\section{Collection of aqueous humor}

Before the first dose of IVG and 1 week after IVG (before the second dose), $100-150 \mu \mathrm{l}$ of anterior aqueous humor was obtained through paracentesis at 9 o'clock by using a sharp 27-gauge needle. Undiluted aqueous samples of $0.05 \mathrm{ml}$ from each eye were collected in a sterilized plastic corning ( $2 \mathrm{~mL}$; Corning Inc., Troy, MI, USA), placed immediately on ice, and stored at $-80^{\circ} \mathrm{C}$ until use. The samples were assayed within 6 months of collection.

\section{Measurement of CMV DNA}

A real-time PCR was applied immediately to detect the amount of CMV DNA load in the samples. Liferiver CMV Real-Time PCR Kit Mix contains reagents and enzymes for the specific amplification of immediate early gene region of the HCMV-DNA. A standard curve was obtained from the quantitation standard CMV DNA-positive controls provided by the manufacturer. For the PCR amplification, $4 \mathrm{ml}$ of the DNA sample was added to $36 \mathrm{ml}$ of the working master mix. The amplicons were then detected by measuring fluorescence, using the Roche LightCycle 480 real-time PCR system with the following amplification conditions: $37^{\circ} \mathrm{C}$ for $2 \mathrm{~min}, 94^{\circ} \mathrm{C}$ for $2 \mathrm{~min}$, followed by 40 cycles of $93{ }^{\circ} \mathrm{C}$ for $15 \mathrm{~s}$ and $60^{\circ} \mathrm{C}$ for $1 \mathrm{~min}$.

\section{Measurement of interleukin-8}

The concentrations of IL-8 in the aqueous humor from cytomegalovirus patients were measured by applying a cytometric bead array (BD Bioscience, San Jose, CA) with flow cytometry (BD FACSCalibur, BD Bioscience, San Jose, CA) [15]. The minor level of detection for IL-8 was $10 \mathrm{pg} / \mathrm{ml}$.

\section{Measurement of trace elements}

Totally, $50 \mu \mathrm{l}$ of aqueous humor was used for elements analysis. $0.075 \mathrm{ml} 20 \mathrm{ng} / \mathrm{ml} \mathrm{RE}$ solution (obtained from National Center of Analysis and Testing for Nonferrous Metals and Electronic Materials) was added, and aqueous humor samples were diluted with a solution of $1 \% \mathrm{HNO} 3$ (UP level, Suzhou pinrui Chemical Co., Ltd.) to $1.5 \mathrm{ml}$. For all analytical procedures, de-ionized glass wares and ultrapure water (electrical resistivity $>18.2 \mathrm{M} \Omega$ ) were used. Levels of calcium $(\mathrm{Ca})$, potassium $(\mathrm{K})$, magnesium $(\mathrm{Mg})$, sodium $(\mathrm{Na})$, phosphorus $(\mathrm{P})$, titanium $(\mathrm{Ti})$, vanadium $(\mathrm{V})$, chromium $(\mathrm{Cr})$, manganese $(\mathrm{Mn})$, iron $(\mathrm{Fe})$, nickel $(\mathrm{Ni})$, copper $(\mathrm{Cu})$, zinc $(\mathrm{Zn})$, selenium $(\mathrm{Se})$, strontium $(\mathrm{Sr})$, lead $(\mathrm{Pb})$ were estimated by inductively coupled-plasma-massspectrometry (ICP-MS) [9]. Quality was controlled with certified standards. The ICP-MS had radio frequency power of $1550 \mathrm{~W}$, a plasma gas flow of $15 \mathrm{~L} / \mathrm{min}$, auxiliary gas flow of $0.8 \mathrm{~L} / \mathrm{min}$ and a nebulizer gas flow of $1.0 \mathrm{~L} / \mathrm{min}$. The mass spectrometer settings were a dwell time of $50 \mathrm{~ms}$, single-point peak hopping for scanning model. The minor level of detection for each element listed in Table 1.

\section{Statistical analysis}

Statistical analysis of the data was performed using a commercially available statistical software package (SPSS for Mac, version 20.0: IBM Corp., NY, USA). Data are 
Table 1 The detection limits and wave length of trace elements

\begin{tabular}{|c|c|c|c|c|c|c|c|c|c|c|c|c|c|c|c|c|}
\hline Elements & $\mathrm{P}$ & $\mathrm{Mg}$ & $\mathrm{Na}$ & $\mathrm{K}$ & $\mathrm{Ca}$ & $\mathrm{Ti}$ & $\mathrm{V}$ & $\mathrm{Cr}$ & $\mathrm{Mn}$ & $\mathrm{Fe}$ & $\mathrm{Ni}$ & $\mathrm{Cu}$ & $\mathrm{Zn}$ & $\mathrm{Se}$ & $\mathrm{Sr}$ & $\mathrm{Pb}$ \\
\hline Wave length (nm) & 178.2 & 279.5 & 589.592 & 766.49 & 396.8 & 41 & 51 & 52 & 55 & 56 & 60 & 63 & 66 & 78 & 88 & 208 \\
\hline Detection limits (ng/mL) & 5.81 & 0.91 & 12.7 & 41.98 & 1.15 & 0.044 & 0.003 & 0.046 & 0.028 & 0.115 & 0.016 & 0.403 & 0.022 & 0.328 & 0.049 & 0.002 \\
\hline
\end{tabular}

presented as the mean \pm standard deviation (SD). A Shapiro-Wilk test was performed to examine whether the samples were distributed normally. The distribution of trace elements and CMV DNA in aqueous humor was considered skewed. The Mann-Whitney $U$ test was used to compare levels of trace elements and amount of CMV particles in aqueous humor of patients with and without CMVR, which including Bonferroni correction $a=0.05 / 16=0.003$. Differences of age between the study group and the control group were estimated with $t$ test. Fisher's exact test was used to compare non-continuous variables. A Wilcoxon signed rank test was used for pre- and post-injection data. The Pearson correlation test was then used to explore the relationship between the aqueous level of each element and the amount of CMV DNA load. Two tailed probabilities of less than 0.05 in Kruskal-Wallis $H$ test and less than 0.003 in Mann-Whitney rank-sum test were considered to indicate statistical significance.

\section{Results}

The study included 15 eyes of 11 patients with CMVR and 24 eyes of 24 patients with senile cataract as control group. Gender was not significantly different between the groups ( $p=0.478$, Table 2). Spearman's correlation tests between age and concentrations of $\mathrm{Ca}, \mathrm{K}, \mathrm{Mg}, \mathrm{Na}, \mathrm{P}, \mathrm{Ti}, \mathrm{V}, \mathrm{Cr}, \mathrm{Mn}$, $\mathrm{Fe}, \mathrm{Ni}, \mathrm{Cu}, \mathrm{Zn}, \mathrm{Se}, \mathrm{Sr}$, and $\mathrm{Pb}$ in the control group were performed to exclude age as a confounding factor. Most of correlation tests showed that age was not significantly associated with the element levels in control group ( $p=$ $0.491,0.894,0.263,0.010,0.02,0.432,0.140,0.544$, $0.482,0.293,0.990,0.304,0.052,0,657,0.021$ and 0.102 , respectively).

Patients with CMVR had significantly higher levels of $\mathrm{P}$ $(29.92 \pm 10.66 \mu \mathrm{g} / \mathrm{mL}$ vs. $16.69 \pm 3.99 \mu \mathrm{g} / \mathrm{mL} ; p<0.001)$, and $\mathrm{Cu} \quad(39.79 \pm 33.73 \mathrm{ng} / \mathrm{mL}$ vs. $9.81 \pm 14.88 \mathrm{ng} / \mathrm{mL}$; $p<0.001)$ when compared with patients without CMVR. Levels of $\mathrm{K} \quad(109.63 \pm 12.30 \mu \mathrm{g} / \mathrm{mL}$ vs. $127.77 \pm 8.76$; $p<0.001)$ and $\mathrm{Mg}(12.57 \pm 2.98 \mu \mathrm{g} / \mathrm{mL}$ vs. $15.98 \pm 1.87$; $p<0.001)$ were significantly reduced in patients with CMVR when compared to those without. No significant differences in the aqueous humor levels of other trace elements were observed between patients with or without CMVR (Table 3, Fig. 1).

The concentration of the aqueous IL- 8 and CMV DNA load declined after intravitreal injections of ganciclovir
Table 2 The clinical information of patients in the cytomegalovirus retinitis (CMVR) and the control group

\begin{tabular}{lllc}
\hline Patients & CMVR & Cataract & $p$ Value \\
\hline Number & 11 & 24 & - \\
Age (years) & $31.18 \pm 13.42$ & $72.46 \pm 11.83$ & $<0.001^{\mathrm{a} *}$ \\
Female (\%) & 27.3 & 41.7 & $0.478^{\mathrm{b}}$ \\
\hline
\end{tabular}

${ }^{a}$ Student $t$ test

${ }^{\mathrm{b}}$ Fisher's exact test

*Statistically significant differences at $p<0.05$

( $p=0.001, p=0.011$, respectively). However, there is no significant change of trace element levels after the treatment (all $p>0.05$ ) (Table 4).

We performed pearson correlation test on the transformed data of a decadic logarithm scale. The concentration of IL-8 in the aqueous humor was significantly associated with the aqueous level of $\mathrm{Cu}(p=0.009, r=0.646)$ and $\mathrm{Se}$ $(p=0.031, r=0.558)$, but not significantly associated with $\mathrm{Ca}(p=0.536, r=-0.173), \mathrm{K}(p=0.520, r=-0.180)$, $\mathrm{Mg}(p=0.189, r=0.359), \mathrm{Na}(p=0.716, r=0.103)$, $\mathrm{P} \quad(p=0.581, \quad r=0.155), \quad \mathrm{Ti} \quad(p=0.795, \quad r=0.073)$, $\mathrm{V}(p=0.687, r=0.114), \mathrm{Cr}(p=0.685, r=0.114), \mathrm{Mn}$ $(p=0.852, \quad r=-0.053), \quad \mathrm{Fe} \quad(p=0.052, \quad r=-0.511)$, Ni $(p=0.758, r=0.087), \mathrm{Zn}(p=0.924, r=-0.027), \mathrm{Sr}$ $(p=0.142, r=-0.398)$, and $\mathrm{Pb}(p=0.795, r=-0.073)$. Meanwhile, the concentration of CMV DNA load in the aqueous humor was significantly associated with the aqueous level of $\mathrm{Ca}(p=0.027, r=-0.568), \mathrm{Mn}(p=$ $0.020, r=0.593)$, and $\mathrm{Cu}(p=0.043, r=0.527)$, but not significantly associated with $\mathrm{K}(p=0.877, r=-0.044)$, $\mathrm{Mg}(p=0.837, r=-0.058), \mathrm{Na}(p=0.356, r=-0.251)$, $\mathrm{P} \quad(p=0.058, \quad r=0.499), \quad$ Ti $(p=0.480, \quad r=0.198)$, $\mathrm{V}(p=0.449, r=0.212), \mathrm{Cr}(p=0.364, r=0.253), \mathrm{Mn}$ $(p=0.020, \quad r=-0.593), \quad$ Fe $(p=0.193, r=-0.356)$, $\mathrm{Ni}(p=0.210, r=0.344), \mathrm{Cu}(p=0.043, r=0.527), \mathrm{Zn}$ $(p=0.371, r=-0.249), \operatorname{Se}(p=0.351, r=0.259), \operatorname{Sr}(p=$ $0.125, r=0.414)$, and $\mathrm{Pb}(p=0.501, r=-0.188)$ (Fig. 2).

\section{Discussion}

Previous studies have demonstrated that the potential of highly active antiretroviral therapy-related immune recovery has altered the course of CMV retinitis [3, 4, 16]. It is likely that patients with immune recovery will have decreased rates of progression of retinitis. Trace elements 
Table 3 The trace elements in patients with CMVR and patients with cataract and without CMVR (control group)

\begin{tabular}{lccc}
\hline Patients & CMVR before injection & Cataract & $p$ value \\
\hline Number (eyes) & 15 & 24 & - \\
$\mathrm{Ca}(\mu \mathrm{g} / \mathrm{mL})$ & $50.26 \pm 27.84$ & $48.80 \pm 5.51$ & 0.470 \\
$\mathrm{~K}(\mu \mathrm{g} / \mathrm{mL})$ & $109.63 \pm 12.30$ & $127.77 \pm 8.76$ & $<0.001^{*}$ \\
$\mathrm{Mg}(\mu \mathrm{g} / \mathrm{mL})$ & $12.57 \pm 2.98$ & $15.98 \pm 1.87$ & $0.001^{*}$ \\
$\mathrm{Na}(\mu \mathrm{g} / \mathrm{mL})$ & $3193.31 \pm 224.00$ & $3174.75 \pm 134.88$ & 0.784 \\
$\mathrm{P}(\mu \mathrm{g} / \mathrm{mL})$ & $29.92 \pm 10.66$ & $16.69 \pm 3.99$ & $<0.001^{*}$ \\
$\mathrm{Ti}(\mathrm{ng} / \mathrm{mL})$ & $5.33 \pm 2.97$ & $5.07 \pm 3.65$ & 0.554 \\
$\mathrm{~V}(\mathrm{ng} / \mathrm{mL})$ & $0.58 \pm 0.40$ & $0.44 \pm 0.33$ & 0.326 \\
$\mathrm{Cr}(\mathrm{ng} / \mathrm{mL})$ & $1.68 \pm 1.15$ & $4.40 \pm 9.96$ & 0.862 \\
$\mathrm{Mn}(\mathrm{ng} / \mathrm{mL})$ & $3.27 \pm 2.55$ & $4.50 \pm 3.82$ & 0.225 \\
$\mathrm{Fe}(\mathrm{ng} / \mathrm{mL})$ & $140.69 \pm 146.83$ & $85.33 \pm 138.47$ & 0.008 \\
$\mathrm{Ni}(\mathrm{ng} / \mathrm{mL})$ & $1.11 \pm 0.78$ & $5.09 \pm 17.52$ & 0.066 \\
$\mathrm{Cu}(\mathrm{ng} / \mathrm{mL})$ & $39.79 \pm 33.73$ & $9.81 \pm 14.88$ & $<0.001^{*}$ \\
$\mathrm{Zn}(\mathrm{ng} / \mathrm{mL})$ & $152.95 \pm 110.64$ & $128.51 \pm 44.61$ & 0.954 \\
$\mathrm{Se}(\mathrm{ng} / \mathrm{mL})$ & $8.42 \pm 4.32$ & $5.62 \pm 2.05$ & 0.058 \\
$\mathrm{Sr}(\mathrm{ng} / \mathrm{mL})$ & $25.01 \pm 16.75$ & $27.50 \pm 11.21$ & 0.126 \\
$\mathrm{~Pb}(\mathrm{ng} / \mathrm{mL})$ & $1.24 \pm 0.80$ & $0.70 \pm 0.36$ & 0.010 \\
\hline $\mathrm{M}$ & & &
\end{tabular}

Mann-Whitney test

*Test including Bonferroni correction, $a=0.003, p<0.003$ are essential for the host defense against infection and repair immune response [17, 18]. Changes in the levels of micronutrients have been described in inflammatory responses, including Behcet's disease and retinitis pigmentosa [10, 11, 17]. However, up to now, there is no report on the aqueous humor levels of trace elements in patients with CMVR.

In this study, we observed significantly higher aqueous humor levels of $\mathrm{P}, \mathrm{Fe}, \mathrm{Cu}$, and $\mathrm{Pb}$, while the levels of $\mathrm{K}$ and $\mathrm{Mg}$ reduced in patients with CMVR. This observation agrees with previous reports that in Behcet's disease, retinitis pigmentosa and AMD [10, 11, 17]. $\mathrm{Zn}$ and $\mathrm{Cu}$ had distinct distributions in the neural retina, retinal pigment epithelium and choroid [8]. The essential metals $\mathrm{Cu}$ and $\mathrm{Zn}$ play vital roles in retinal cell survival and are crucial for the normal functioning of antioxidant enzymes. Considering oxidative stress, iron as $\mathrm{Fe}(\mathrm{II})$, promotes formation of free radicals, especially in the retina $[18,19]$. From our data, we found no evidence of abnormal $\mathrm{Zn}$ in CMVR patients, at least in this patient population. This might be due to small sample size or different ethnic groups.

After intravitreal injections of ganciclovir, the levels of trace elements showed no significant change, while the
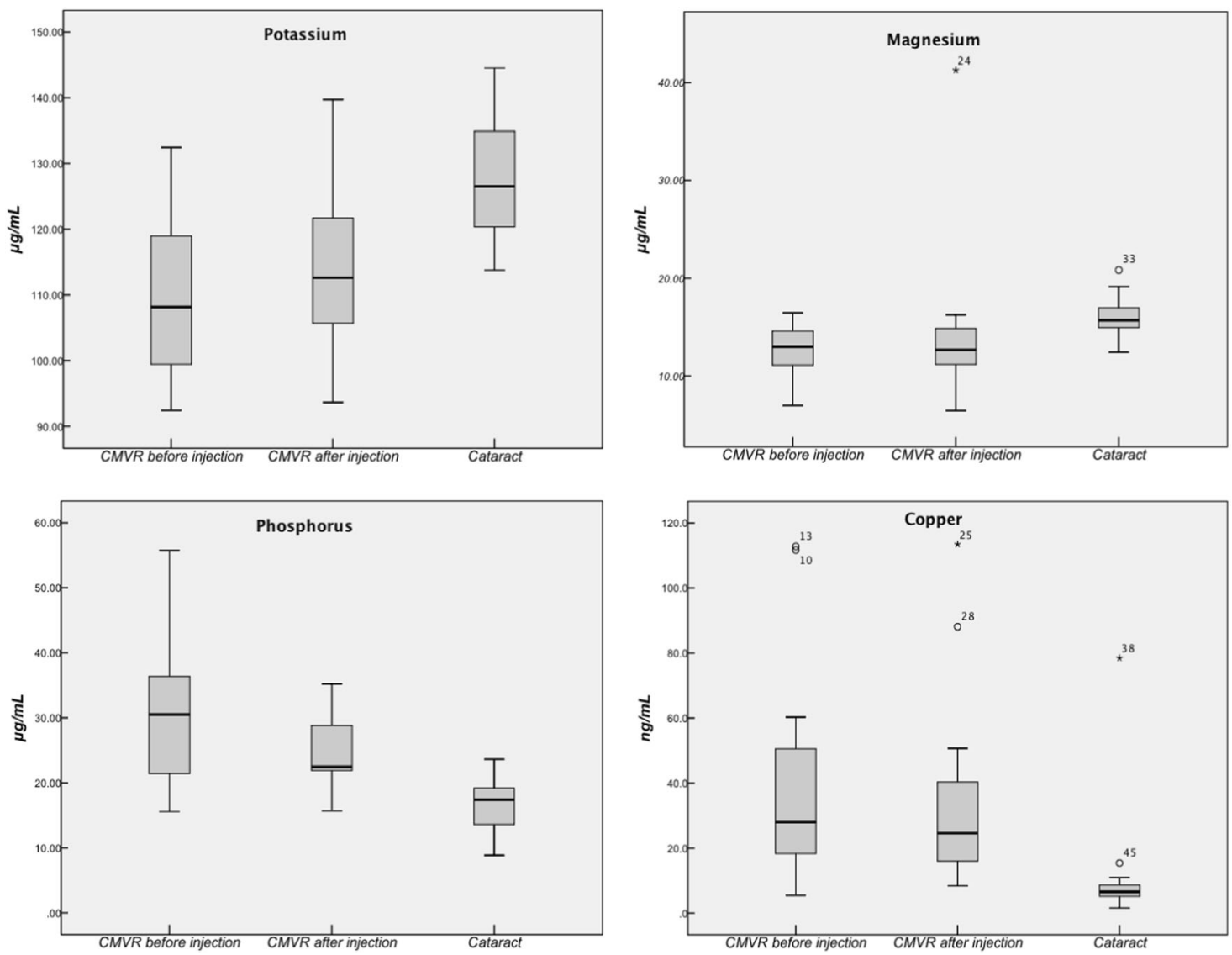

Fig. 1 Differences in the levels of aqueous humor trace elements in group of patients with CMVR before injection of ganciclovir, after injection of ganciclovir and control group 
Table 4 The changes of trace elements in patients with CMVR after injection of ganciclovir

\begin{tabular}{lccc}
\hline Patients & CMVR before injection & CMVR after injection & $p$ Value \\
\hline Number(eyes) & 15 & 15 & \\
$\mathrm{IL}-8(\mathrm{pg} / \mathrm{mL})$ & $491.15 \pm 723.06$ & $132.70 \pm 160.98$ & $0.001^{*}$ \\
$\mathrm{CMV}$ DNA (copies/ml) & $254,712.67 \pm 502,653.90$ & $158,139.47 \pm 526,914.44$ & $0.011^{*}$ \\
$\mathrm{Ca}(\mu \mathrm{g} / \mathrm{mL})$ & $50.26 \pm 27.84$ & $46.39 \pm 18.51$ & 0.865 \\
$\mathrm{~K}(\mu \mathrm{g} / \mathrm{mL})$ & $109.63 \pm 12.30$ & $113.73 \pm 12.34$ & 0.088 \\
$\mathrm{Mg}(\mu \mathrm{g} / \mathrm{mL})$ & $12.57 \pm 2.98$ & $14.34 \pm 7.94$ & 0.977 \\
$\mathrm{Na}(\mu \mathrm{g} / \mathrm{mL})$ & $3,193.31 \pm 224.00$ & $25.30 \pm 5.88$ & 0.865 \\
$\mathrm{P}(\mu \mathrm{g} / \mathrm{mL})$ & $29.92 \pm 10.66$ & $5.83 \pm 3.33$ & 0.191 \\
$\mathrm{Ti}(\mathrm{ng} / \mathrm{mL})$ & $5.33 \pm 2.97$ & $0.44 \pm 0.23$ & 0.955 \\
$\mathrm{~V}(\mathrm{ng} / \mathrm{mL})$ & $0.58 \pm 0.40$ & $1.10 \pm 0.75$ & 0.394 \\
$\mathrm{Cr}(\mathrm{ng} / \mathrm{mL})$ & $1.68 \pm 1.15$ & $3.00 \pm 1.50$ & 0.363 \\
$\mathrm{Mn}(\mathrm{ng} / \mathrm{mL})$ & $3.27 \pm 2.55$ & $104.59 \pm 87.99$ & 0.733 \\
$\mathrm{Fe}(\mathrm{ng} / \mathrm{mL})$ & $140.69 \pm 146.83$ & $1.72 \pm 2.05$ & 0.065 \\
$\mathrm{Ni}(\mathrm{ng} / \mathrm{mL})$ & $1.11 \pm 0.78$ & $34.91 \pm 29.62$ & 0.570 \\
$\mathrm{Cu}(\mathrm{ng} / \mathrm{mL})$ & $39.79 \pm 33.73$ & $181.01 \pm 222.78$ & 0.233 \\
$\mathrm{Zn}(\mathrm{ng} / \mathrm{mL})$ & $152.95 \pm 110.64$ & $8.87 \pm 4.62$ & 0.609 \\
$\mathrm{Se}(\mathrm{ng} / \mathrm{mL})$ & $8.42 \pm 4.32$ & $22.85 \pm 6.71$ & 0.807 \\
$\mathrm{Sr}(\mathrm{ng} / \mathrm{mL})$ & $25.01 \pm 16.75$ & $1.64 \pm 1.30$ & 0.609 \\
$\mathrm{~Pb}(\mathrm{ng} / \mathrm{mL})$ & $1.24 \pm 0.80$ & & 0.427 \\
\hline $\mathrm{W} i \mathrm{cox})$ & & &
\end{tabular}

Wilcoxon signed rank test

*Statistically significant differences at $p<0.05$
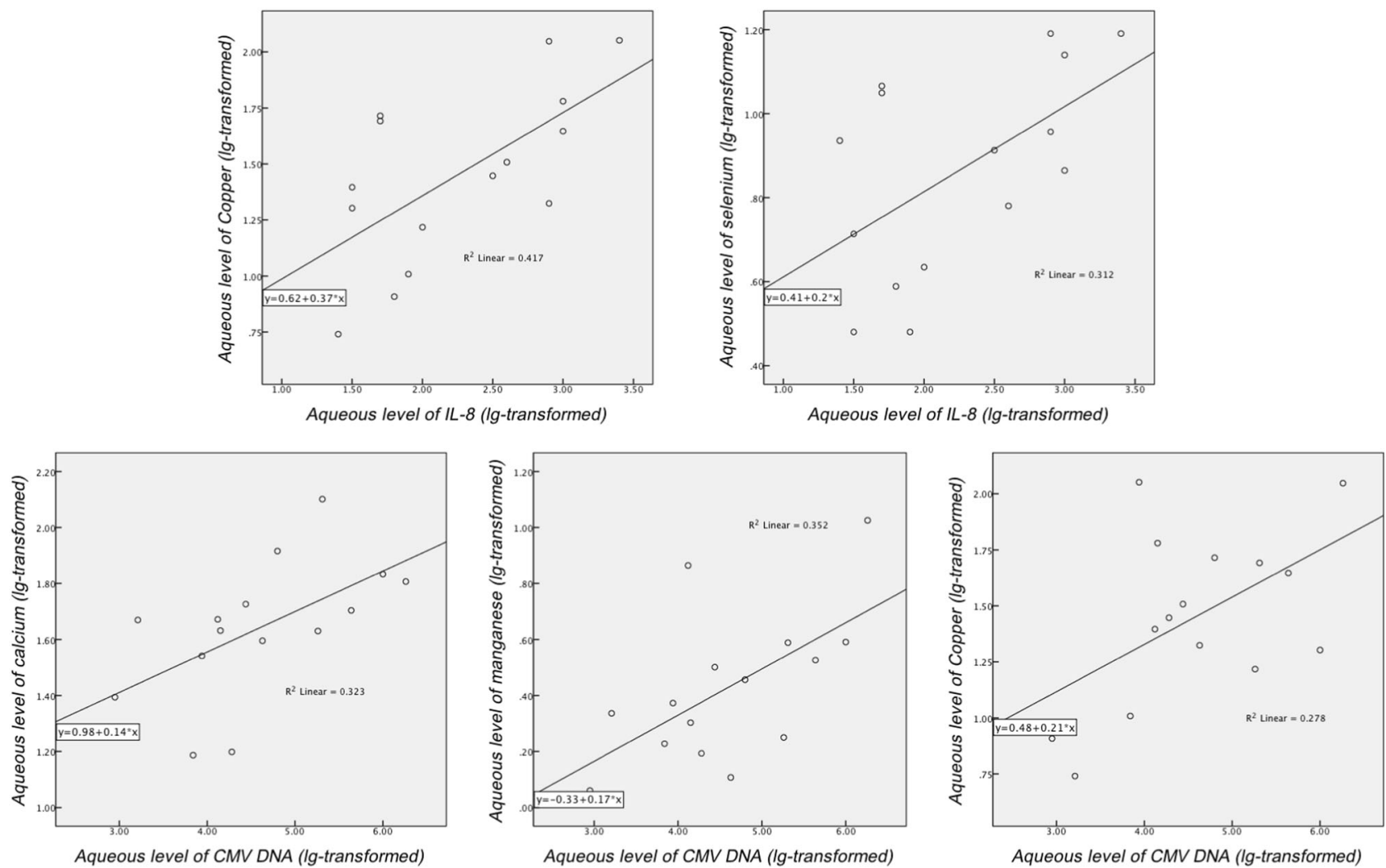

Fig. 2 Scatterplots showing the association between the level of trace element and the level of IL-8 or CMV DNA load 
concentration of the aqueous IL-8 and CMV DNA load declined. But we noticed that the level of $\mathrm{Cu}$ had significantly positive correlation with both of the concentration of IL-8 and CMV DNA load. CMVR secondary to varied systemic diseases including AIDS or immunosuppressive treatment. Copper has been established as an acute phase reactant and its level in serum have been shown to change significantly in a range of acute and chronic infective, inflammatory, and neoplastic processes owing to increased reproductive of ceruloplasmin [20]. Serum $\mathrm{Cu}$ has been shown to return to normality after overcoming the initial acute phase of the associated disease. This finding is consistent with previous reports that found significant higher serum copper in HIVseropositive subjects [21, 22].

Levels of CMV in anterior aqueous humor of patients with CMVR could be an indicator of disease activity just like levels of HIV in serum of patients with AIDS [13]. Our previous study has reported that IL-8 was significantly associated with the aqueous level of CMV copies and continuously declined during multiple intravitreal injections of antiviral drugs [14]. Considering the level of $\mathrm{Cu}$ had positive correlation with both of the concentration of IL-8 and CMV DNA load in present study. The level of $\mathrm{Cu}$ has a big chance to be a good quantitative laboratory indicator of CMVR. Aqueous humor collected after only one injection, not multiple injections. This could be the reason that the level of $\mathrm{Cu}$ did not show significant decline after the treatment. Nevertheless, the role of $\mathrm{Cu}$ acts in inflammation or immune during the development of CMVR disease need to be explored.

Certainly, there are still some limitations in our study. First, the patients of the study group were younger than the subjects of the control group (Table 1). The reason for the difference in age between the two groups is that senile cataract usually occurs in an older age than does CMVR patients. Therefore, the patients of the study group were younger, than the subjects of the control group. It is true that age is an obligatory confounder. Because the likelihood of an abnormal condition usually increases with age, one therefore may infer that the difference in age between study group and control group only strengthens the conclusions drawn. Furthermore, we performed Spearman's correlation tests between age and concentrations of each element in control group, which excluded age as a confounding factor for the remarked element. One may believe that the age influence did not remarkably affect the present conclusion. Second, our findings should be considered preliminary; we have only examined the levels of trace elements in the aqueous humor, which is inaccurate to assume that a particular element is released as a result of the disease process or the cause of a disease process. Finally, the number of enrolled patients was not large, because of the low prevalence of CMVR, and the study nevertheless was retrospective in design.

In conclusion, these findings give us an interesting hint that knowledge of trace elements distribution, metabolism and toxicity will help to understand their role in the pathogenesis of CMVR. Alterations of the trace elements levels indicate that micronutrient homeostasis may involve in the pathogenesis of CMVR. Especially, $\mathrm{Cu}$ was significantly higher in the aqueous humor of CMVR patients, and positively associated with the aqueous level of CMV DNA copies and IL-8. Thus, the roles of trace element differences in ocular balance warrant further investigation as factors in CMVR.

\section{Study Highlights}

\section{What was known before}

- Cytomegalovirus retinitis (CMVR) is a common opportunistic infection that afflicts immunocompromised patients. And Immune recovery has resulted in an approximate $80 \%$ reduction in the incidence of CMVR, and patients with CMVR who have immune recovery are less likely to have progression of retinitis. Trace elements are needed for micronutrient homeostasis, which plays a major role in maintaining a healthy immune system.

\section{What this study adds}

- These findings give us an interesting hint that knowledge of trace elements distribution, metabolism and toxicity will help to understand their role in the pathogenesis of CMVR.

Acknowledgements This study was supported by the 1351 talent training program (No. CYXX-2017-21). The study was conducted in accordance with the Declaration of Helsinki, and we received approval from the Investigational Review Board of the Beijing Chaoyang Hospital. Informed consent was obtained from each patient after an explanation of the purpose and potential adverse effects of the procedure.

\section{Compliance with ethical standards}

Conflict of interest The authors declare that they have no conflict of interest.

Publisher's note: Springer Nature remains neutral with regard to jurisdictional claims in published maps and institutional affiliations. 


\section{References}

1. Carmichael A. Cytomegalovirus and the eye. Eye. 2012;26: 237-40.

2. Gupta MP, Patel S, Orlin A, Marlow E, Chee RI, Nadelmann J, et al. Spectral domain optical coherence tomography findings in macula-involving cytomegalovirus retinitis. Retina. 2018;38: 1000-10.

3. Jabs DA. Aids and ophthalmology, 2008. Arch Ophthalmol. 2008;126:1143-6.

4. Jabs DA, Van Natta ML, Thorne JE, Weinberg DV, Meredith TA, Kuppermann BD, et al. Studies of Ocular Complications of ARG: Course of cytomegalovirus retinitis in the era of highly active antiretroviral therapy: 1. Retinitis progression. Ophthalmology. 2004;111:2224-31.

5. Thorne JE, Van Natta ML, Jabs DA, Duncan JL, Srivastava SK. Studies of ocular complications of ARG: visual field loss in patients with cytomegalovirus retinitis. Ophthalmology. 2011;118:895-901.

6. Ferreira CR, Gahl WA. Disorders of metal metabolism. Transl Sci Rare Dis. 2017;2:101-39.

7. Wisniewska M, Cremer M, Wiehe L, Becker NP, Rijntjes E, Martitz J, et al. Copper to zinc ratio as disease biomarker in neonates with early-onset congenital infections. Nutrients 2017;9:343.

8. Wills NK, Ramanujam VM, Kalariya N, Lewis JR, van Kuijk FJ. Copper and zinc distribution in the human retina: relationship to cadmium accumulation, age, and gender. Exp Eye Res. 2008;87: $80-88$.

9. Junemann AG, Stopa P, Michalke B, Chaudhri A, Reulbach U, Huchzermeyer $\mathrm{C}$, et al. Levels of aqueous humor trace elements in patients with non-exsudative age-related macular degeneration: a case-control study. PLoS ONE. 2013;8:e56734.

10. Atmaca LS, Arcasoy A, Cavdar AO, Ozmert E. Levels of zinc in plasma, erythrocytes, and hair, and levels of serum copper in patients with retinitis pigmentosa in turkey. $\mathrm{Br} \mathrm{J}$ Ophthalmol. 1989;73:29-31.

11. Saglam K, Serce AF, Yilmaz MI, Bulucu F, Aydin A, Akay C, et al. Trace elements and antioxidant enzymes in Behcet's disease. Rheuma Int. 2002;22:93-96.
12. Gammoh NZ, Rink L: Zinc in infection and inflammation. Nutrients 2017;9:624.

13. Miao H, Tao Y, Jiang YR, Li XX. Multiple intravitreal injections of ganciclovir for cytomegalovirus retinitis after stem-cell transplantation. Graefes Arch Clin Exp Ophthalmol. 2013;251: 1829-33.

14. Wang B, Tian B, Tao Y, Hou J, Zhao XT, Li XX. Continued decline of aqueous interleukin-8 after multiple intravitreal injections of ganciclovir for cytomegalovirus retinitis. J Ocul Pharm Ther. 2014;30:587-92.

15. Miao H, Tao Y, Li XX. Inflammatory cytokines in aqueous humor of patients with choroidal neovascularization. Mol Vis. 2012;18: 574-80.

16. Jabs DA, Van Natta ML, Thorne JE, Weinberg DV, Meredith TA, Kuppermann BD, et al. Studies of ocular complications of ARG: course of cytomegalovirus retinitis in the era of highly active antiretroviral therapy: 2. Second eye involvement and retinal detachment. Ophthalmology. 2004;111:2232-9.

17. Crouch RK, Chambers JK. Absence of abnormal erythrocyte superoxide dismutase, copper, or zinc levels in patients with retinitis pigmentosa. Br J Ophthalmol. 1982;66:417-21.

18. Rogers BS, Symons RC, Komeima K, Shen J, Xiao W, Swaim ME, et al. Differential sensitivity of cones to iron-mediated oxidative damage. Invest Ophthalmol Vis Sci. 2007;48:438-45.

19. Hohberger B, Chaudhri MA, Michalke B, Lucio M, Nowomiejska $\mathrm{K}$, Schlotzer-Schrehardt U, et al. Levels of aqueous humor trace elements in patients with open-angle glaucoma. J Trace Elem Med Biol. 2018;45:150-5.

20. Powanda MC. Changes in body balances of nitrogen and other key nutrients: description and underlying mechanisms. Am J Clin Nutr. 1977;30:1254-68.

21. Moreno T, Artacho R, Navarro M, Perez A, Ruiz-Lopez MD. Serum copper concentration in HIV-infection patients and relationships with other biochemical indices. Sci Total Environ. 1998; 217:21-26.

22. Graham NM, Sorensen D, Odaka N, Brookmeyer R, Chan D, Willett WC, et al. Relationship of serum copper and zinc levels to hiv-1 seropositivity and progression to aids. J Acquir Immune Defic Syndr. 1991;4:976-80. 